\title{
Heart Surgery in a Male Patient with Blood Group OH (Bombay Phenotype) - A Rare Case Report
}

\author{
MD. MAZIBUR RAHMAN ${ }^{1}$, SHEIKH MUHAMMAD SHAHEEDUL ISLAM ${ }^{2}$, MD. SIRAJUL ISLAM ${ }^{3}$, AYESHA \\ KHATUN $^{4}$, JALAL UDDIN ${ }^{1}$, MD.ASHRAF UDDIN SULTAN ${ }^{5}$
}

\begin{abstract}
${ }^{1}$ Department of Cardiac Surgery, Ibrahim Cardiac Hospital \& Research Institute, Dhaka, ${ }^{2}$ Department of Cardiology, Ibrahim Cardiac Hospital \& Research Institute, Dhaka, ${ }^{3}$ Department of Cardiac Anaesthesia., Ibrahim Cardiac Hospital \& Research Institute, Dhaka , ${ }^{4}$ Department of Transfusion Medicine, Bangabandhu Sheikh Mujib, Medical University, Dhaka, ${ }^{5}$ Department of Cardiology, Bangabandhu Sheikh Mujib, Medical University, Dhaka
\end{abstract}

Address for correspondence: $\quad$ Dr. Md. Mazibur Rahman, Consultant, Department of Cardiac Surgery, Ibrahim Cardiac Hospital \& Research Institute, Shahbag, Dhaka, E-mail: drmuzib2009@yahoo.co

\begin{abstract}
:
A 59 years old gentleman with hypertension, type-2 DM, dyslipidemia and atheroschlerotic stenosing coronary artery disease had the rare blood group Oh ((Bombay phenotype). After prophylactic conservation of two units of predeposit autologous blood, myocardial revascularization was successfully accomplished with off pump coronary artery bypass surgery (OPCAB). Postoperative recovery was uneventful.
\end{abstract}

Key words:Bombay phenotype, OPCAB

\section{Introduction:}

The Bombay phenotype is an extremely rare blood group type with genetically suppressed A, B and $\mathrm{H}$ genes. The $\mathrm{H}$ gene is possessed by nearly all normal people .Full expression of $\mathrm{A}, \mathrm{B}$ and $\mathrm{O}$ alleles depend on the presence of at least one $\mathrm{H}$ gene, not only to express $\mathrm{H}$-ness of red cells but also A-ness or B-ness in the presence of an $\mathrm{A}$ or B gene. ${ }^{1}$ So $\mathrm{H}$ substance is an essential factor for the synthesis of A, B and $\mathrm{H}$ antigens on red cells by the direct action of gene-enzyme-red cell membrane. The Bombay type is very peculiar too; because in routine tests for blood grouping it is a $\mathrm{O}$ type, but during crossmatching procedure donor's O-type cells get clumped with the serum of Bombay type recipient. As Bombay type possess supressed $\mathrm{H}$-gene. The serum contains anti- $\mathrm{H}$ antibody as an A or B-type serum does anti-B or anti-A respectively as a natural protector. So during elective surgery or in emergency getting a compatible donor is crucial. This very peculiar type of blood is one of the rarest in the world except in India especially in south India, Bengal and Uttar Pradesh. ${ }^{1,2,3}$ It was first discovered in a patient in Seth Gordhandas Sunderdas Medical College in Bombay (now known as Mumbai) in India by Dr. Bhende in 1952,,1,4 hence the name Bombay blood. The symbol Oh is now used to describe the phenotype (Genotype hh) of these cells which have been also called hh bloods. ${ }^{1,5}$

The frequency of this Bombay phenotype (Oh) is around 1: $13,000^{1}$ in South state (Moharastra) the Marathi speaking people of Bombay with an estimated h gene frequency of $0.0066^{3}$ where consanguineous marriage is permitted $^{4,6}$ and the condition mainly occurs in small closed off communities where the recessive gene has a chance to find two parents with this same blood group.Due to the presence of anti- $\mathrm{H}$ antibody in the plasma of $\mathrm{Oh}$ phenotype, when considering such patients for transfusion, only blood of identical Bombay type can be safely transfused. ${ }^{3}$

We are reporting a patient having Bombay phenotypic blood underwent myocardial revascularization surgery using autotransfusion while he had critical lesion in coronary arteries.

There has been only one report regarding Bombay phenotypic blood (Oh) and heart surgery in German language.

The purpose of this publication is to learn how other centres manage such with a rare blood group and how we managed this situations and to describe our experience too (It is a review article).

\section{Case report:}

A 59 years old Bangladeshi gentleman with hypertension, type $2 \mathrm{DM}$ and dyslipidaemia got admitted in Ibrahim Cardiac Hospital \& Research Institute (ICHRI) for elective coronary artery bypass grafting (CABG) surgery with the past history of inferior MI, occasional constrictive severe central chest pain with radiation to chin, ameliorated with sublingual GTN spray. He underwent CAG that revealed double vessel-disease (DVD): mid LAD 80\% stenosis and a right dominant system having proximal RCA lesion 100\%, 
Table-I

Haematological changes of the patient after blood donation with simultaneous supplementation of rh-EPO with $\mathrm{Fe}^{+}$before and after operation.

\begin{tabular}{|c|c|c|c|c|c|c|c|c|}
\hline \multirow[t]{2}{*}{ Donation } & \multirow[t]{2}{*}{ Interval } & \multicolumn{7}{|c|}{ Haematological changes } \\
\hline & & $\mathrm{Hb} \%$ & $\mathrm{RBC}$ & HCT & MCV & $\mathrm{MCH}$ & MCHC & Platelet \\
\hline $\begin{array}{l}\text { Before donation of } \\
1^{\text {st }} \text { unit }\end{array}$ & & $14 \mathrm{~g} / \mathrm{dl}$ & $4.59 \mathrm{~m} / \mathrm{mm}^{3}$ & $40 \%$ & 87.1fl & 30.5pg & $35 \mathrm{~g} / \mathrm{dl}$ & $160 \mathrm{k} / \mu \mathrm{l}$ \\
\hline $\begin{array}{l}\text { Before donation of } \\
2^{\text {nd }} \text { unit }\end{array}$ & 4 days & $10.6 \mathrm{~g} / \mathrm{dl}$ & $3.39 \mathrm{~m} / \mathrm{mm}^{3}$ & $29.6 \%$ & 87.3fl & 31.3pg & $35.3 \mathrm{~g} / \mathrm{dl}$ & $175 \mathrm{k} / \mathrm{\mu l}$ \\
\hline Before operation & 4 days & $13.8 \mathrm{~g} / \mathrm{dl}$ & $4.25 \mathrm{~m} / \mathrm{mm}^{3}$ & $37.1 \%$ & 87.3fl & $32.5 p g$ & $37.2 \mathrm{~g} / \mathrm{dl}$ & $188 \mathrm{k} / \mu \mathrm{l}$ \\
\hline $\begin{array}{l}\text { Immediately after } \\
\text { operation }\end{array}$ & & $11.6 \mathrm{~g} / \mathrm{dl}$ & $3.9 \mathrm{~m} / \mathrm{mm}^{3}$ & $34.6 \%$ & $87.6 f l$ & 32.0pg & $36.2 \mathrm{~g} / \mathrm{dl}$ & $178 \mathrm{k} / \mu \mathrm{l}$ \\
\hline $\begin{array}{l}1^{\text {st }} \text { postoperative. } \\
\text { Day(POD) }\end{array}$ & & $9.1 \mathrm{~g} / \mathrm{dl}$ & $3.0 \mathrm{~m} / \mathrm{mm}^{3}$ & $27.3 \%$ & 92.1fl & $34.2 \mathrm{pg}$ & $36.9 \mathrm{~g} / \mathrm{dl}$ & $200 \mathrm{k} / \mu \mathrm{l}$ \\
\hline Day Before discharge & & $8.3 \mathrm{~g} / \mathrm{dl}$ & $2.86 \mathrm{~m} / \mathrm{mm}^{3}$ & $26.2 \%$ & $89.5 f l$ & 32pg & $36.8 \mathrm{~g} / \mathrm{dl}$ & $175 \mathrm{k} / \mu \mathrm{l}$ \\
\hline $\begin{array}{l}\text { Time of discharge } \\
\text { ( } 7^{\text {th }} \text { POD) }\end{array}$ & & $10.9 \mathrm{~g} / \mathrm{dl}$ & $3.58 \mathrm{~m} / \mathrm{mm}^{3}$ & $32 \%$ & $89.4 \mathrm{fl}$ & $30.4 \mathrm{pg}$ & $34.0 \mathrm{~g} / \mathrm{dl}$ & $138 \mathrm{k} / \mu \mathrm{l}$ \\
\hline
\end{tabular}

not amenable to PTCA. So he was recommended for CABG. ECG showed old inferior myocardial infarction, on CXR no abnormality detected. Echo revealed mild and distal inferior wall hypokinesia, isolated septal hypertrophy and dilated left atrium, Tricuspid regurgitation (Grade I) and mild pulmonary hypertension. PASP - 37 mmHg, Diastolic dysfunction (Grade I) with Ejection Fraction- 55\%.

His blood group was 'O', Rh (D)-positive in routine grouping procedure after admission in our hospital. But it was found incompatible with all units of donors blood during crossmatching the day before operation. So operation was postponed. Later on, a sample of blood from the patient was sent to the Transfusion Department in Bangabandhu Shaikh Mujib Medical University (BSMMU) for evaluation and confirmation of blood group. The blood group of the patient was confirmed as Oh (Bombay phenotype), Rh (D) positive. In the absence of compatible allogeneic blood, predeposit autotransfusion was planned before the operation. Two units of self blood donation in 4 days interval were performed in the blood bank of the same institute with supplementation of oral iron (350 mg/day $\mathrm{Fe}^{+}$) in addition to recombinant human erythropoietin (rh-EPO 10,000 units subcutaneously) during each donation under optimal monitoring before the operation. The haematological changes are shown in Table-I.

In April, 2009 direct myocardial revascularization was carried out by aorto coronary vein bypass to the left anterior descending (LAD) and to the right coronary artery
(RCA) under off-pump coronary artery bypass (OPCAB) with proper haemostasis and minimal blood loss.

This Bombay phenotypic patient tolerated the two units of blood donation before the CABG operation, without any adverse events or complication. One unit of autologous blood was transfused on first postoperative day, and the other unit before the discharge from hospital after checking all haematological parameters. Haemodynamic and haematologic parameters showed no marked changes after the donation of autologous blood. Post operative morbidity including stroke, renal impairment/ failure, prolonged ventilation and pulmonary complications were absent.

\section{Discussion:}

The patient was diagnosed after admission for cardiac surgery as having $\mathrm{O}$ blood group but showed incompatibility with donors blood of same group. He was sent for further investigations and found to have Bombay phenotypic (Oh) blood which is rare in our country. So he was prepared for autotransfusion to prevent mismatch transfusion. The Bombay phenotype (Oh) is characterized by group " $\mathrm{O}$ " that lacks $\mathrm{H}$ antigen on red cells and by the presence of anti- $\mathrm{H}$ along with anti-A and anti- B in serum. 2,7 Anti- $\mathrm{H}$ is directed against the heterogenic basic substance which exists with the blood group O, A, B \& AB. Hence when anti- $\mathrm{H}$ of a person with Bombay phenotype reacts with erythrocyte of blood group “O. It is mainly an IgM antibody which is incapable to cross the placenta during 
pregnancy and might not lead to haemolytic disease of newborn (HDN). 1,4

Individuals with Bombay phenotype blood must be transfused with blood from other Bombay phenotype individuals, ${ }^{4}$ otherwise it will lead to severe haemolytic transfusion reaction and intravascular compliment activation $^{4}$ which can be fatal. Bombay phenotype individuals lack $\mathrm{ABH}$ antigens on red cells and possess corresponding alloantibody in serum, ${ }^{1,7}$ the antibodies reacts equally well at $37^{\circ} \mathrm{C}$ and at $4^{\circ} \mathrm{C}$. $5,7,9,10$

In India, the incidence of Bombay phenotype is $1: 13000^{1}$ especially in Moharastra and the frequency of $h$ gene is $0.0066^{1}$ where consanguineous marriage is permitted ${ }^{4}$ and the condition mainly occurs in small closed off communities where two heterozygous ( $\mathrm{Hh}$ ) individuals if marry each other, then $25 \%$ of the offspring would be expected to be $h^{1}{ }^{1}$. The problem arises whenever anybody having Bombay phenotypic blood needs urgent transfusion(e.g. Accidental injury), he/she might be simply out of luck as it would be pretty unlikely that any blood bank would have any in stock. In such an emergency situation, if he/she is transfused accidentally with O group blood, may lead to acute severe haemolytic transfusion reaction which is fatal and may lead to death. Thus Davey and employee ${ }^{4}$ proved that ${ }^{51} \mathrm{Cr}$ marked erythrocyte of group $\mathrm{O}$ are diminished very fast by using anti-H of Bombay phenotype but anybody who is planned for an elective operation in anticipation of transfusion in near future (e.g. cardiac surgery), he/she should have to follow the procedures of predeposit autotransfusion (in which patients donate blood over a period of time in a number of occasions at 4-7 days intervals in preparation for an elective operation within 21-35 days in anticipation of a future need) with or without use of preoperative isovolumic haemodilution (in which blood is removed in theatre immediate preoperatively and volume replacement is given and the blood is reinfused postoperatively) or intraoperative salvage transfusion (in which harvesting of blood shed at surgery or in similar circumstances, which is reinfused immediately or after concentration \& purification). With the customary preservation of predeposit autologous blood with safekeeping at temperature between $2^{\circ}-8^{\circ} \mathrm{C}$ in normal way of blood bank storage, only five units of blood can be collected during a number of occasions at 4-7 days intervals within 21-35 days of limited conservation period with or without "leap frog technique" (in which the autologous donation of first unit in the usual way, at a second session, donation of two units instead of one, and receives the original donation back again. Thus he has effectively just lost only one unit of blood but two fresh units are available with a full shelf life ahead of them. This method can be repeated as necessary) $)^{10}$ before an elective surgery. Thus several units of predeposit autologous blood through normal blood bank storage at $2^{\circ}-8^{\circ} \mathrm{C}$ can be achieved with the sacrifice of some cellular elements (e.g. platelet) and coagulation factors within 21-35 days preservation of blood. Also here we utilized predeposit autologous blood, preserved in blood bank at a temperature of $2^{\circ}-8^{\circ} \mathrm{C}$ for our patient with Bombay phenotype (Oh). It is safe and cost effective method, can be used by the poor countries during any situation of rare group of blood.

Our past experience on 1000 cases of beating heart surgery which showed minimal blood loss and transfusion perioperatively, never exceeded 2 units of blood per case. As coronary angiogram revealed LAD lesion 80\% and RCA-100\%, we decided to do OPCAB surgery which can be performed even with the expense of 1-2 units of autologous blood to avoid mismatch transfusion. As the patient had critical lesion with occasional chest pain, we decided to do the operation as early as possible. So we collected only 2 units of predeposit autologous blood at 4 days interval with the last donation not less than 4 days before surgery with simultaneously supplementation of recombinant erythropoietin (rh-EPO) and oral Iron .If we would consider the case to be operated on-pump which need 4-6 units of autologous blood, it will be time consuming, which will not be suitable for a patient having critical coronary lesions with occasional chest pain. The collected 2 units of blood was reinfused after the operation when $\mathrm{Hb} \%$ came down at the lower level. We did the operation successfully with 2 units of predeposit autologous blood with uneventful postoperative recovery. To our knowledge, there has been only one German literature report of unusual Oh blood and heart surgery.

Today the method of choice for blood preservation for an indefinite period without appreciable qualitative changes is the "deep freeze conservation" in which separated red cells are simply suspended in hydroxyethyl starch solution and stored in frozen state over liquid nitrogen. Recovery is simply by placing the frozen pack in a $42^{\circ} \mathrm{C}$ water bath for a minute or two, after which the contents are infused without further manipulation. ${ }^{10}$ This technique of “deep freeze preservation" is used by the developed countries with autologous blood in a patient undergoing elective operation with rare blood group or where possibility of transfusion transmitted infection (TTI) are present. ${ }^{4}$ If available, this method is superior and can be 
utilized for anybody who needs predeposit autologous blood transfusion in future especially for rare blood group. Any surgical procedure which needs large volume of blood (e.g. Cardiac surgery) with rare group can utilize autotransfusion following deep freeze storage of his/her own blood with or without preoperative isovolumic haemodilution or peroperative salvage transfusion either singly or in combination with or without extracorporeal circulation.

\section{Conclusion:}

Predeposite autologous blood transfusion is safe, simple and cost effective method for reducing the need for allogeneic transfusion especially in the dire need for rare blood group transfusion like Bombay phenotype (Oh) or where transfusion transmitted infection (TTI) and lack of sensitive assays like Enzyme-linked immunosorbent assay (ELISA), nucleic acid testing (NAT.) and lack of trained personnel are still cause for concern. It is feasible and safe if optimal monitoring of the patient during and after each donation is met. It can play a part in rendering transfusion safer and in economizing on scarce supply of donor blood. So preoperative autologous blood donation is an effective means for all patients for all surgeries including cardiac surgerys in adult as well as in paediatric where large volume of blood transfusion is needed.

\section{References:}

1. Rahman M, Abdullah AZ, Husain M, Haque KM, Hossain MM. A Bangladeshi family with 3 sisters Bombay or Oh Phenotype. Bangladesh Medical Research Council bulletin 1990; 16(2): 75-85

2. Bhende YM, Deshpande CK, Bhatia HM, et al. A “new" blood group character related to the ABO system, Lancet. 1951, 903-04.

3. Simmon's RT, D'Sena GW. Anti-H in group O blood J Indian Med Assoc 1955; 24: 325

4. Schricker KT, Neidhardt B, Hacker R und kail R, Herzo peration BEI einer patientin mit der Blutgruppe Oh (Bombayphenotype). Dtsch Med Wochenschr. 198314, 108: 61-63.

5. Klein HG, Anstee DJ. ABO, Lewis and P groups and Li antigens. In: Mollison's Blood transfusion in Clinical Medicine, $11^{\text {th }}$ edition, Blackwell Publishing, Inc; Mainstreet, Melden, Massachusetts 02148, USA. P-119

6. Bhatia HM, Sanghvi LD. Rare blood group and sanguinity; Bombay phenotype.Vox Sang.1962; 7: 245-48.

7. Pourazar A, Joshi S, Clarke VA, Ala F. Another case of paraBombay phenotype in an Iranian donor. Archives of Iranian medicine 2000; 7(4): 284-86.

8. Moores PP, Blood group of the natal Indian people [PhD thesis].Durban, South Africa: Natal University; 1980

9. Bhatia HM. Serologic reactions of $\mathrm{ABO}$ and Oh Phenotype due to variations in $\mathrm{H}$ antigens. In: Mohn JF, Plunkett RN, Cunningham RK, Lambert RM, eds. Human blood groups. $1^{\text {st }}$ ed Basel: Karger,1977:296

10. Slater NGP: Autologous blood transfusion. Malaysian J pathol 1991; 13(2): 67-73. 